\title{
Analisis Arsitektur Aplikasi Web Menggunakan Model View Controller (MVC) pada Framework Java Server Faces
}

\author{
Gunawan', Armin Lawi', Adnan ${ }^{3}$ \\ ${ }^{1}$ STMIK Handayani UIN Alauddin Makassar, Makassar, ${ }^{2}$ Jurusan Matematika, Universitas Hasanuddin, \\ Makassar, ${ }^{3}$ Prodi Teknik ElektroUniversitas Hasanuddin, Makassar \\ Email: ${ }^{1}$ gunawan@uin-alauddin.ac.id, ${ }^{2}$ armin@unhas.ac.id, ${ }^{3}$ adnan@unhas.ac.id
}

\begin{abstract}
Abstrak
Aplikasi web yang khususnya memiliki kompleksitas besar dalam melakukan transaksi data sehingga konsep arsitektur (pattern) perlu menjadi perhatian khusus untuk dapat mengoptimalkan kinerja performansi sistem ketika pengguna (user) menggunakan dalam waktu yang bersamaan dengan jumlah yang banyak. Analisis performa arsitektur aplikasi web yang menggunakan model 2 (MVC) dengan menggunakan framework Java Server Faces (JSF) dan model 1 sebagai pembanding. Metode yang digunakan adalah Load dan Scalability Testing dengan dua cara yaitu uji coba terhadap response time karena peningkatan ukuran dari database dan uji coba terhadap response time karena peningkatan jumlah user yang menggunakan sistem secara bersamaan (concurrent users) dan waktu tunggu (ramp-up) yang ditentukan menggunakan Apache Jmeter. Analisis menunjukkan bahwa dalam implementasi arsitektur web yang menggunakan model 1 waktu rata-rata yang dibutuhkan untuk merespon permintaan user lebih cepat dan efisien dibanding model 2 (MVC).
\end{abstract}

Kata kunci: MVC, Load and scalability, Java server faces, Jmeter

\section{PENDAHULUAN}

Tren teknologi aplikasi berbasis web mengalami perubahan yang sangat signifikan pada proses bisnis ataupun presentasi. Aplikasi web yang khususnya memiliki kompleksitas besar dalam melakukan transaksi data dan konsep arsitektur (pattern) perlu menjadi perhatian khusus untuk dapat mengoptimalkan kinerja performansi sistem ketika pengguna (user) menggunakan dalam waktu yang bersamaan dengan jumlah yang banyak. Konsep arsitektur yang paling populer saat ini adalah arsitektur Model 1dan arsitektur Model 2 (MVC).

Arsitektur Model 1 logika bisnis (business-logic) dan presentasi (view) digabungkan dalam satu komponen web. Hal ini tidak menjadi masalah jika logika bisnis dan presentasi masih relatif sederhana. Namun jika logika menjadi semakin kompleks, pendekatan ini akan menjadi masalah dimana jika proses bisnis dan presentasi dibangun menjadi satu dapat menyulitkan para pengembang (developer) ketika melakukan perubahan presentasi atau proses bisnis karena ketergantungan yang tinggi antara presentasi dan proses bisnis. Arsitektur Model 2 (MVC) merupakan konsep pada beberapa framework aplikasi web dimana memisahkan pengembangan aplikasi berdasarkan komponen utama seperti manipulasi data, user interface dan bagian yang menjadi kontrol aplikasi. Dengan MVC aplikasi web dapat dikembangkan sesuai dengan kemampuan pengembang, misalnya programmer yang menangani bagian model dan controller, sedangkan designer yang menangani bagian view, sehingga dapat meningkatkan maintainability dan organisasi kode yang lebih mudah. 
Ada banyak jenis framework yang dapat digunakan untuk mengimplementasikan MVC diantaranya yaitu Java Server Faces (JSF), Struts, Seam, Codeigniter, CakePHP, WebWork, Spring, Yii, dan sebagainya. Setelah dilakukan implementasi arsitektur web dengan load dan scalability testing menggunakan Apache Jmeter, waktu rata-rata yang dibutuhkan web Model 1 untuk merespon permintaan user lebih cepat dan efisien dengan jumlah Concurent user (Number of Thread) yang banyak dalam waktu bersamaan dibanding model 2 (MVC) begitu juga pada penggunaan resource memori dan CPU Model 1 lebih unggul. Model 2 memerlukan waktu untuk melakukan load library dan parser kode (source) dalam hal interaksi pola karena pemisahan bagian kode yaitu Model - View - Controller. Selain itu, perubahan nilai stack size pada sistem operasi juga mempengaruhi kinerja aplikasi web dimana semakin tinggi nilai stack size maka kebutuhan memori semakin besar pula.

\section{METODE}

\subsection{Model View Controller (MVC)}

Untuk membangun aplikasi web sebelumnya menggunakan konsep atau arsitektur yang disebut dengan arsitektur Model 1.

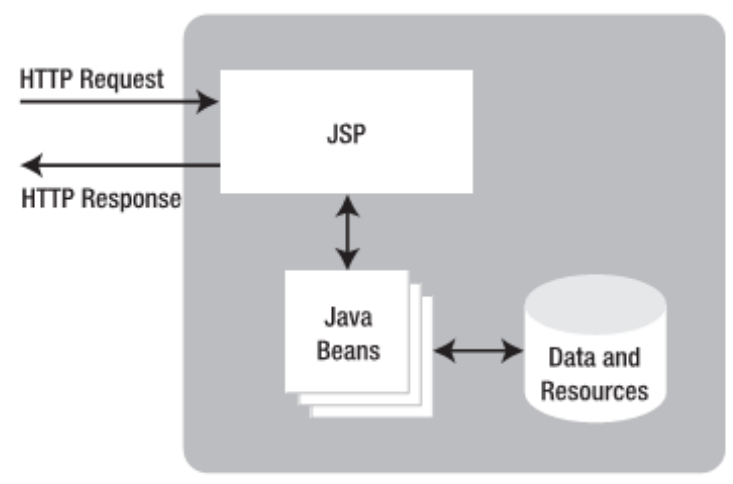

Gambar 1. Arsitektur Model 1

Dalam arsitektur Model 1, HTTP request diterima oleh sebuah komponen web (misalnya Java Server Page (JSP) atau servlet). Kemudian request diproses dan langsung dihasilkan response yang biasanya berupa halaman HTML. Selain itu dalam arsitektur Model 1, logika bisnis (business-logic) dan presentasi (view) digabungkan dalam satu komponen web. Hal ini tidak menjadi masalah jika logika bisnis dan presentasi masih relatif sederhana. Namun jika logika menjadi semakin kompleks, pendekatan ini bisa menjadi masalah. Arsitektur Model 2, atau Model View Controller (MVC) kemudian diperkenalkan untuk mengatasi masalah tersebut [1]. MVC adalah pola desain atau arsitektur yang digunakan dalam rekayasa perangkat lunak, dimana terjadi pemisahan yang jelas antara data (model), dengan user interface (view) [2]. MVC merupakan model atau metode untuk membuat aplikasi dengan memisahkan data (model) dari tampilan (view) dan bagaimana memprosesnya (controller) [3]. 
Arsitektur Model 2 sebenarnya implementasi server-side dengan membagi aplikasi menjadi bagian-bagian tersendiri yaitu Sumber data sebagai Model, representasi atau tampilan dengan View dan pemrosesan sebagai Controller. Lebih jelasnya adalah sebagai berikut:

1. Model, merupakan implementasi dari logika bisnis dan data bisnis. Model dapat direalisasi dengan memakai sembarang komponen web.

2. View, merupakan implementasi dari presentasi, yaitu halaman yang akan dipakai sebagai response untuk dikirimkan kepada client. View akan menampilkan data bisnis yang telah diolah. Umumnya yang paling cocok dipakai adalah halaman JSP.

3. Controller, merupakan pengontrol aliran request (data). Tugasnya adalah menerima request yang dikirimkan dari client. Data request akan diolah atau diteruskan kepada komponen lain yang mengolah data. Pada akhirnya request yang diolah akan diserahkan kepada komponen view. Umumnya dipakai servlet sebagai controller.

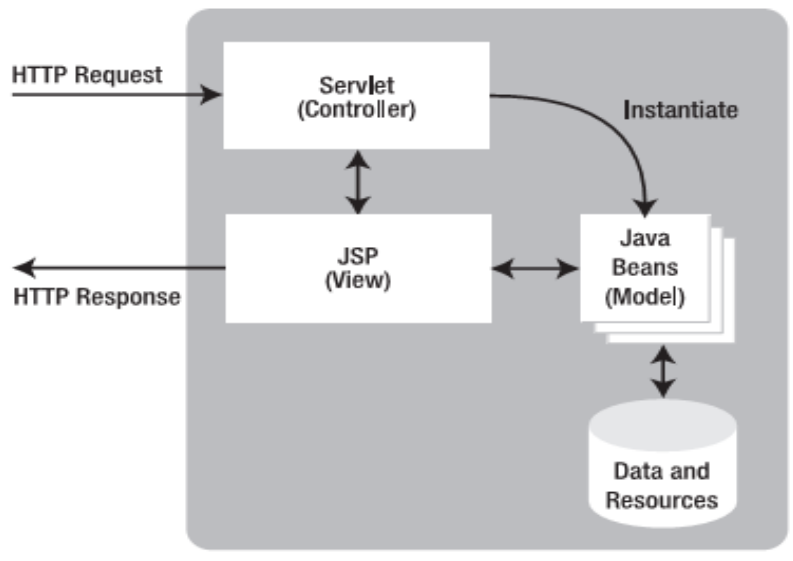

Gambar 2. Arsitektur Model 2 (MVC)

Arsitektur MVC ini memungkinkan adanya perubahan dalam domain model tanpa harus mengubah kode untuk menampilkan domain model tersebut. Hal ini sangat bermanfaat ketika aplikasi mempunyai domain model dan view komponen sangat besar dan kompleks. Sehingga konsep MVC diperkenalkan untuk teknologi aplikasi web khususnya berskala besar atau kompleks (enterprise).

\subsection{Java Server Faces}

Menurut Bauer [4] Java Server Faces (JSF) adalah user interface framework dalam bahasa Java untuk membangun aplikasi web. JSF merupakan salah satu bagian dari teknologi pada platform Java EE. JSF diciptakan pada tahun 2002 melalui Java Specification Request (JSR) 127. Salah satu kelebihan utama dari JSF adalah teknologi ini menawarkan pembagian yang jelas antara layer presentasi dan bisnis. 


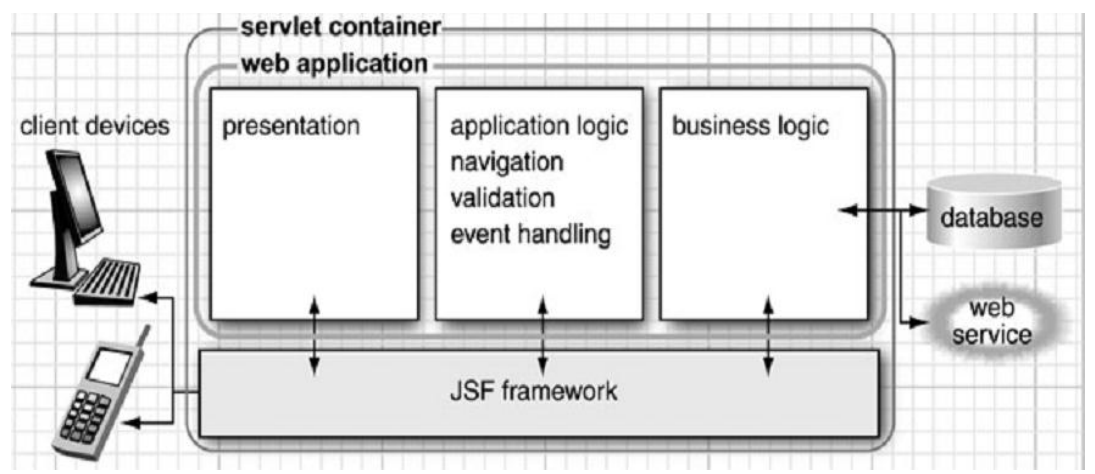

Gambar 3. Arsitektur Java Server Faces

Pada Gambar 3 di atas terlihat bahwa JSF bertanggung jawab dalam menangani interaksi klien dan aplikasi, menghubungkan bagian presentasi, logic aplikasi dan bussiness logic menjadi suatu aplikasi web. Sub sistem lainnya, seperti layanan EJB atau basis data dapat diintegrasikan dengan mudah walaupun bukan merupakan bagian dari JSF.

Proses detail framework JSF bekerja dapat diilustrasikan pada Gambar 4 dan Gambar 5.

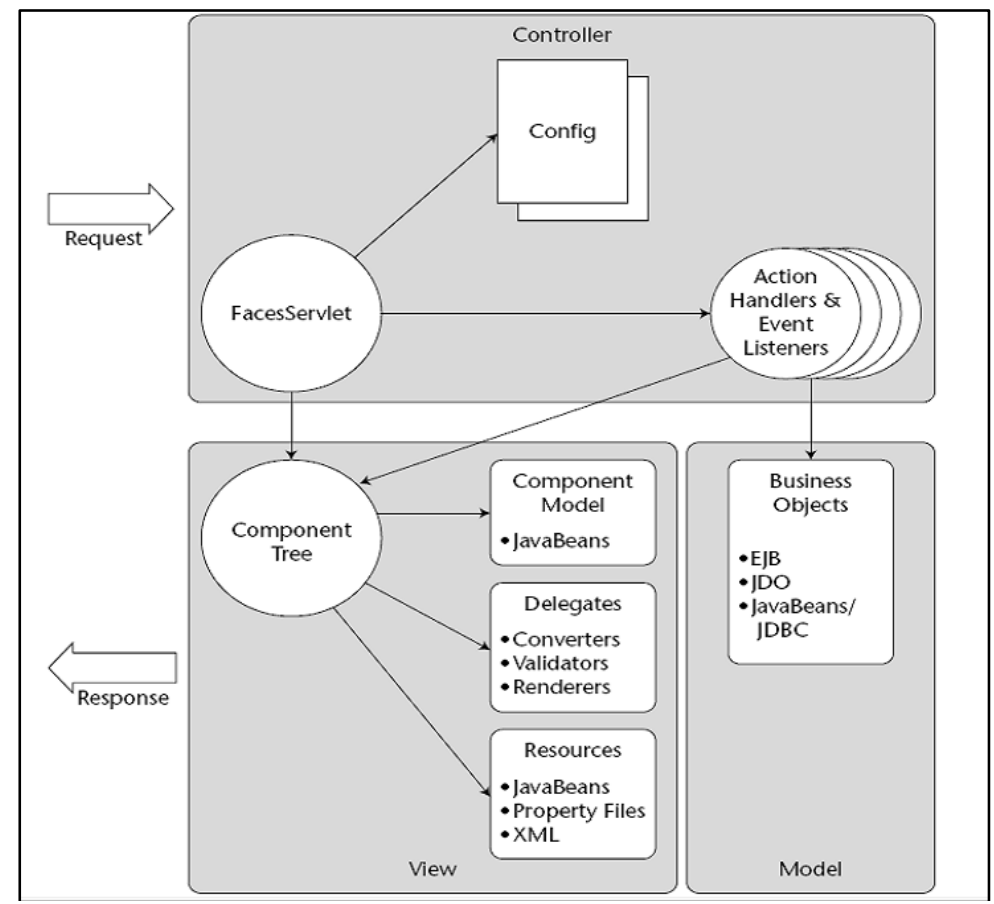

Gambar 4. Java server faces framework 


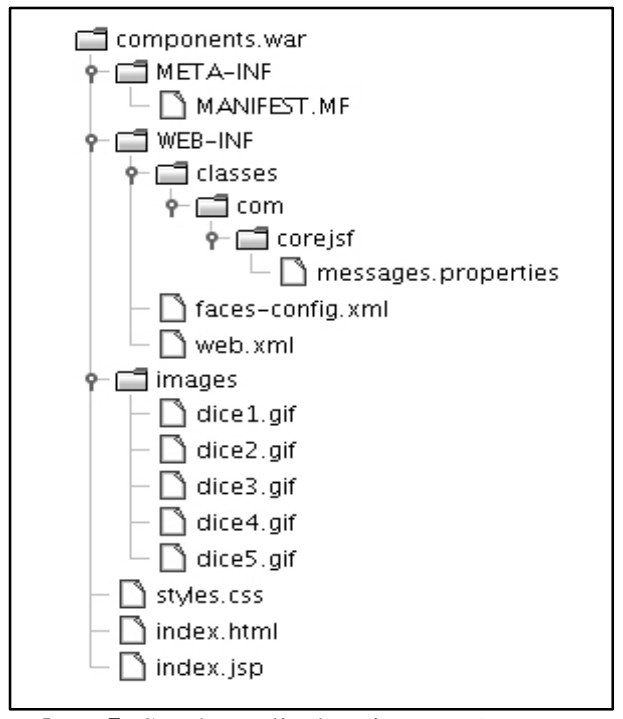

Gambar 5. Struktur direktori Java Server Faces

Implementasi model 2 atau model view controller (MVC) telah dilakukan pada sistem informasi katalog online atau Online Publik Access Catalog (OPAC) studi kasus Universitas Islam Negeri Alauddin Makassar. Pada tahapan ini lebih menekankan analisis performansi arsitektur aplikasi website dengan metode uji Load dan Scalability Test pada Model 2 atau Model View Controller (MVC) dan Model 1 sebagai pembanding dengan penerapan metode mengikuti tahapan seperti pada Gambar 6.

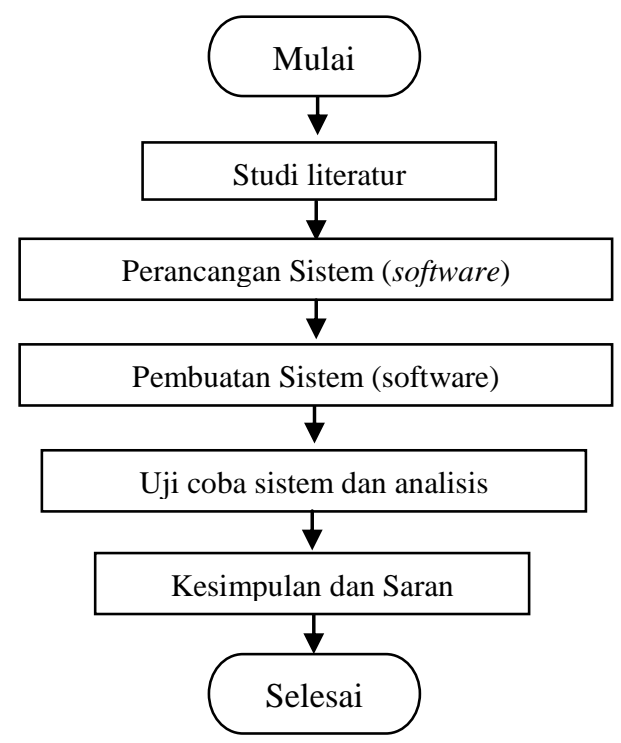

Gambar 6. Diagram tahapan 
Tahapan secara garis besar dijelaskan sebagai berikut:

a. Studi literatur, tahap ini untuk mencari informasi konsep pengujian sistem pada aplikasi website dengan metode Load dan Scalability Testing menggunakan Apache Jmeter, maka perlu dilakukan studi literatur dari berbagai sumber.

b. Perancangan sistem, tahap ini dilakukan perancangan sistem aplikasi web dengan menggunakan konsep atau arsitektur Model 1 dan Model 2 (MVC), untuk mendukung proses pengujian dan analisis.

c. Pembuatan sistem, tahap ini merupakan proses pembuatan program sistem aplikasi web dengan menggunakan konsep atau arsitektur Model 1 dan Model 2 (MVC).

d. Uji coba sistem dan analisis, tahap pengujian dilakukan untuk menguji kerja dari keseluruhan sistem menggunakan metode Load dan Scalability Testing yang mencakup:

1. Pengujian terhadap response time terhadap peningkatan jumlah user yang menggunakan sistem secara bersamaan (concurrent users) sekaligus penggunaan memori dan CPU.

2. Pengujian terhadap response time terhadap peningkatan ukuran database sekaligus penggunaan memori dan CPU.

Tahap analisis dilakukan untuk menganalisa hasil pengujian sistem terhadap efisiensi dan efektifitas performansi arsitektur aplikasi web yang menggunakan arsitektur Model 2 atau Model View Controller (MVC) pada framework Java Server Faces (JSF).

\section{HASIL DAN PEMBAHASAN}

\subsection{Hasil Pengujian Load dan Scalability}

Hasil pengujian yang telah dilakukan dengan menggunakan 1 komputer client dapat dilihat pada Tabel 1.

Tabel 1. Data hasil pengujian

\section{Web Statis}

\begin{tabular}{lcrrrrrrr}
\hline \multicolumn{7}{c}{ Web Statis } \\
\hline \multirow{2}{*}{ Arsitektur Samples Average Min } & Max & $\begin{array}{r}\text { Std. } \\
\text { Dev. }\end{array}$ & $\begin{array}{r}\text { Error } \\
\text { \% }\end{array}$ & Throughput KB/sec \\
\hline \multirow{2}{*}{ MODEL 1 } & 1 & 6 & 6 & 6 & 0 & $0.00 \%$ & 166.7 & 661.62 \\
& 100 & 4 & 3 & 11 & 1.09 & $0.00 \%$ & 1 & 4.01 \\
& 500 & 3 & 2 & 13 & 1.21 & $0.00 \%$ & 5 & 19.85 \\
\multirow{2}{*}{ MODEL 2 } & 1 & 18 & 18 & 18 & 0 & $0.00 \%$ & 55.6 & 258.14 \\
& 100 & 13 & 11 & 22 & 1.6 & $0.00 \%$ & 1 & 4.69 \\
& 500 & 10 & 7 & 164 & 7.04 & $0.00 \%$ & 5 & 23.25 \\
\hline \multirow{2}{*}{ Arsitektur Samples Average Min } & Max & Std. & Error & Throughput & KB/sec \\
& 1 & 270 & 270 & 270 & 0 & $0.00 \%$ & 3.7 & 27.21 \\
\multirow{2}{*}{ MODEL 1 } & 100 & 14 & 9 & 220 & 20.77 & $0.00 \%$ & 1 & 7.42 \\
& 500 & 12 & 10 & 27 & 1.74 & $0.00 \%$ & 5 & 36.76 \\
& 1 & 189 & 189 & 189 & 0 & $0.00 \%$ & 5.3 & 64.47 \\
\multirow{2}{*}{ MODEL 2 } & 100 & 108 & 53 & 1585 & 219.65 & $0.00 \%$ & 1 & 12.3 \\
& 500 & 2826 & 0 & 18652 & 5296.33 & $69.60 \%$ & 5 & 24.87 \\
\hline \multicolumn{7}{c}{ Web Dinamis 2 } \\
\hline
\end{tabular}




\begin{tabular}{rcrrrrrrr}
\hline \multirow{2}{*}{ Arsitektur Samples Average Min } & Max & $\begin{array}{r}\text { Std. } \\
\text { Dev. }\end{array}$ & $\begin{array}{r}\text { Error } \\
\text { \% }\end{array}$ & Throughput & KB/sec \\
\hline \multirow{2}{*}{ MODEL 1 } & 1 & 714 & 714 & 714 & 0 & $0.00 \%$ & 1.4 & 10.29 \\
& 100 & 17 & 14 & 46 & 3.85 & $0.00 \%$ & 1 & 7.42 \\
& 500 & 14 & 11 & 80 & 3.24 & $0.00 \%$ & 5 & 36.77 \\
MODEL 2 & 1 & 1578 & 1578 & 1578 & 0 & $0.00 \%$ & 0.6 & 7.66 \\
& 500 & 221 & 77 & 3334 & 502.57 & $0.00 \%$ & 1 & 12.15 \\
& 232 & 0 & 7128 & 979.32 & $89.80 \%$ & 5 & 14.38 \\
\hline
\end{tabular}

* Size database tabel buku $915 \mathrm{~KB}$ atau 6015 data.

** Size database tabel buku 1,9 MB atau 12027 data.

Selain melakukan pengujian Load dan Scalability Testing menggunakan Apache Jmeter, dilakukan pula uji performa penggunaan resource memori dan CPU dengan memberikan parameter jumlah thread 100, 200, 400, 800, 2.000, dan 5.000 dimana parameter stack size yang digunakan adalah $1 \mathrm{MB}, 2 \mathrm{MB}, 4 \mathrm{MB}, 8 \mathrm{MB}, 16 \mathrm{MB}, 32$ MB dan 64 MB. Hal ini dilakukan karena konsep pengujian pada aplikasi menggunakan konsep multithreading dimana suatu kemampuan yang memungkinkan beberapa kumpulan instruksi atau proses dapat dijalankan secara bersamaan yang membutuhkan alokasi memori sehingga nilai stack size perlu menjadi pertimbangan dalam pengujian ini.

Hasil pengujian untuk setiap Model menggunakan Apache Jmeter dapat dilihat pada Tabel 2 (Model 1) dan Tabel 3 (Model 2).

Tabel 2. Hasil penggunaan resource memory dan CPU pada Model 1

\begin{tabular}{|c|c|c|c|}
\hline \multirow[b]{2}{*}{$\begin{array}{l}\text { Jumlah } \\
\text { Thread }\end{array}$} & \multirow{2}{*}{$\begin{array}{l}\text { Stack } \\
\text { size } \\
\text { (MB) }\end{array}$} & \multicolumn{2}{|c|}{ Resource } \\
\hline & & $\begin{array}{l}\text { CPU } \\
(\%)\end{array}$ & $\begin{array}{l}\text { Memory } \\
\text { (MB) }\end{array}$ \\
\hline \multirow{7}{*}{100} & 1 & 13.30 & 322.95 \\
\hline & 2 & 11.35 & 945.08 \\
\hline & 4 & 11.11 & 1324.36 \\
\hline & 8 & 11.43 & 1206.81 \\
\hline & 16 & 11.21 & 1337.04 \\
\hline & 32 & 11.13 & 1481.71 \\
\hline & 64 & 11.62 & 1620.68 \\
\hline \multirow{7}{*}{200} & 1 & 13.98 & 336.55 \\
\hline & 2 & 12.65 & 947 \\
\hline & 4 & 11.92 & 1296.69 \\
\hline & 8 & 11.94 & 1206.76 \\
\hline & 16 & 11.96 & 1330.1 \\
\hline & 32 & 12.28 & 1471.78 \\
\hline & 64 & 12.05 & 1623.15 \\
\hline \multirow{7}{*}{400} & 1 & 18.39 & 338.31 \\
\hline & 2 & 14.12 & 948.72 \\
\hline & 4 & 11.92 & 1296.69 \\
\hline & 8 & 13.79 & 1207.7 \\
\hline & 16 & 13.65 & 1309.51 \\
\hline & 32 & 13.69 & 1617.73 \\
\hline & 64 & 13.88 & 1623.87 \\
\hline
\end{tabular}




\begin{tabular}{|c|c|c|c|}
\hline \multirow[b]{2}{*}{$\begin{array}{l}\text { Jumlah } \\
\text { Thread }\end{array}$} & \multirow{2}{*}{$\begin{array}{l}\text { Stack } \\
\text { size } \\
\text { (MB) }\end{array}$} & \multicolumn{2}{|l|}{ Resource } \\
\hline & & $\begin{array}{l}\text { CPU } \\
(\%)\end{array}$ & $\begin{array}{l}\text { Memory } \\
\text { (MB) }\end{array}$ \\
\hline \multirow{7}{*}{800} & 1 & 22.87 & 371.16 \\
\hline & 2 & 19.08 & 900.41 \\
\hline & 4 & 18.59 & 1070.69 \\
\hline & 8 & 18.61 & 1178.85 \\
\hline & 16 & 18.28 & 1245.38 \\
\hline & 32 & 18.33 & 1624.15 \\
\hline & 64 & 18.11 & 1625.25 \\
\hline \multirow{7}{*}{2000} & 1 & 31.15 & 596.88 \\
\hline & 2 & 36.12 & 1047.44 \\
\hline & 4 & 32.25 & 1102.09 \\
\hline & 8 & 34.42 & 1306.11 \\
\hline & 16 & 34.44 & 1347.87 \\
\hline & 32 & 31.14 & 1630.1 \\
\hline & 64 & 28.87 & 1665.83 \\
\hline \multirow{7}{*}{5000} & 1 & error & error \\
\hline & 2 & error & error \\
\hline & 4 & error & error \\
\hline & 8 & error & error \\
\hline & 16 & error & error \\
\hline & 32 & error & error \\
\hline & 64 & error & error \\
\hline
\end{tabular}

Tabel 3. Hasil penggunaan resource memory dan CPU pada Model 2

\begin{tabular}{|c|c|c|c|}
\hline \multirow[b]{2}{*}{$\begin{array}{l}\text { Jumlah } \\
\text { Thread }\end{array}$} & \multirow{2}{*}{$\begin{array}{l}\text { Stack } \\
\text { size } \\
\text { (MB) }\end{array}$} & \multicolumn{2}{|l|}{ Resource } \\
\hline & & $\begin{array}{l}\text { CPU } \\
(\%)\end{array}$ & $\begin{array}{l}\text { Memory } \\
\text { (MB) }\end{array}$ \\
\hline \multirow{7}{*}{100} & 1 & 12.64 & 365.43 \\
\hline & 2 & 12.82 & 495.57 \\
\hline & 4 & 11.31 & 638.26 \\
\hline & 8 & 11.15 & 937.17 \\
\hline & 16 & 11.45 & 999.55 \\
\hline & 32 & 11.03 & 1068.39 \\
\hline & 64 & 11.42 & 1141.84 \\
\hline \multirow{7}{*}{200} & 1 & 14.72 & 365.53 \\
\hline & 2 & 13.54 & 496.76 \\
\hline & 4 & 12.01 & 641.23 \\
\hline & 8 & 12.33 & 938.06 \\
\hline & 16 & 12.01 & 1002.83 \\
\hline & 32 & 11.94 & 1069.42 \\
\hline & 64 & 11.81 & 1142.92 \\
\hline \multirow{7}{*}{400} & 1 & 15.34 & 369.96 \\
\hline & 2 & 14.62 & 515.58 \\
\hline & 4 & 12.34 & 657.35 \\
\hline & 8 & 13.54 & 937.5 \\
\hline & 16 & 13.43 & 1007.09 \\
\hline & 32 & 13.62 & 1071.35 \\
\hline & 64 & 13.81 & 1144.83 \\
\hline \multirow{3}{*}{800} & 1 & 22.24 & 404.96 \\
\hline & 2 & 13.73 & 567.38 \\
\hline & 4 & 24.43 & 858.33 \\
\hline
\end{tabular}




\begin{tabular}{|c|c|c|c|}
\hline \multirow{2}{*}{$\begin{array}{l}\text { Jumlah } \\
\text { Thread }\end{array}$} & \multirow{2}{*}{$\begin{array}{l}\text { Stack } \\
\text { size } \\
\text { (MB) }\end{array}$} & \multicolumn{2}{|l|}{ Resource } \\
\hline & & $\begin{array}{l}\text { CPU } \\
(\%)\end{array}$ & $\begin{array}{l}\text { Memory } \\
\text { (MB) }\end{array}$ \\
\hline & 8 & 19.63 & 957.05 \\
\hline & 16 & 17.31 & 1019.58 \\
\hline & 32 & 17.22 & 1076.21 \\
\hline & 64 & 16.61 & 1149.4 \\
\hline & 1 & 25.48 & 584.92 \\
\hline & 2 & 18.93 & 735.48 \\
\hline & 4 & 18.02 & 898.36 \\
\hline 2000 & 8 & 18.01 & 1073.45 \\
\hline & 16 & 17.93 & 1119.58 \\
\hline & 32 & 17.91 & 1176.21 \\
\hline & 64 & 17.61 & 1249.4 \\
\hline & 1 & error & error \\
\hline & 2 & error & error \\
\hline & 4 & error & error \\
\hline 5000 & 8 & error & error \\
\hline & 16 & error & error \\
\hline & 32 & error & error \\
\hline & 64 & error & error \\
\hline
\end{tabular}

Untuk memudahkan dalam proses analisis sistem, akan diambil sampel salah satu modul yang ada pada masing-masing model atau sistem yaitu halaman Home untuk model statis dan halaman katalog buku untuk model dinamis untuk mempermudah menganalisa dan membandingkan alur (flow) pada model arsitektur 1 dan model arsitektur 2 atau MVC. Proses pengujian dilakukan dengan menggunakan konsep client server, dimana pengujian dilakukan pada 1 komputer server dan 1 komputer sebagai client.

Alur (flow) dalam jalannya sistem model 1 dan model 2 dapat ditunjukkan pada Tabel 4.

Tabel 4. Perbandingan alur (flow) jalannya sistem

\begin{tabular}{|c|c|}
\hline Arsitektur Model 1 & Arsitektur Model 2 (MVC) \\
\hline \multicolumn{2}{|c|}{ Halaman Statis } \\
\hline $\begin{array}{l}\text { Pengunjung/anggota } \text { (user) - } \\
\text { JSP - DAO - JSP - } \\
\text { Pengunjung/anggota (user) }\end{array}$ & $\begin{array}{l}\text { Pengunjung/anggota (user) - } \\
\text { JSP - } \\
\text { faces-config.xml - DAO - JSP } \\
\text { - Pengunjung/anggota (user) }\end{array}$ \\
\hline \multicolumn{2}{|c|}{ Halaman Dinamis } \\
\hline $\begin{array}{l}\text { Pengunjung/anggota (user) - } \\
\text { JSP - DAO - Database - DAO } \\
\text { - JSP - } \\
\text { Pengunjung/anggota (user) }\end{array}$ & $\begin{array}{l}\text { Pengunjung/anggota (user) - } \\
\text { JSP - } \\
\text { faces-config.xml- DAO - } \\
\text { Database - DAO - JSP - } \\
\text { Pengunjung/anggota (user) }\end{array}$ \\
\hline
\end{tabular}

Pada pengujian halaman statis pada kedua sistem, model 1 lebih unggul dalam ratarata waktu merespon permintaan (response time) dibandingkan pada model 2 dengan parameter yang sama yaitu Concurent user (Number of Thread) 1, 100, 500 user dengan permintaan data (loop count) 1 dan jumlah periode ramp-up masing-masing 
10 detik. Pada pengujian ini semua permintaan data dapat direspon dan diproses oleh sistem.

Jika dilihat secara seksama Model 2 terlihat jelas faces-config.xml dan Action mengambil peranan penting dalam alur (flow) jalannya sistem. Pada bagian JSP hanya mengambil data permintaan dari user dan menampilkannya kembali pada user sehingga membutuhkan waktu tanggap (response time) yang lebih lama dibandingkan dengan Model 1 dimana alur jalannya sistem lebih sederhana karena peran JSP sangat bekerja keras menangani permintan (request) data sampai menampilkan kembali pada pengunjung atau anggota (user). Perbandingan rata-rata pengujian ini dapat dilihat pada Gambar 7.

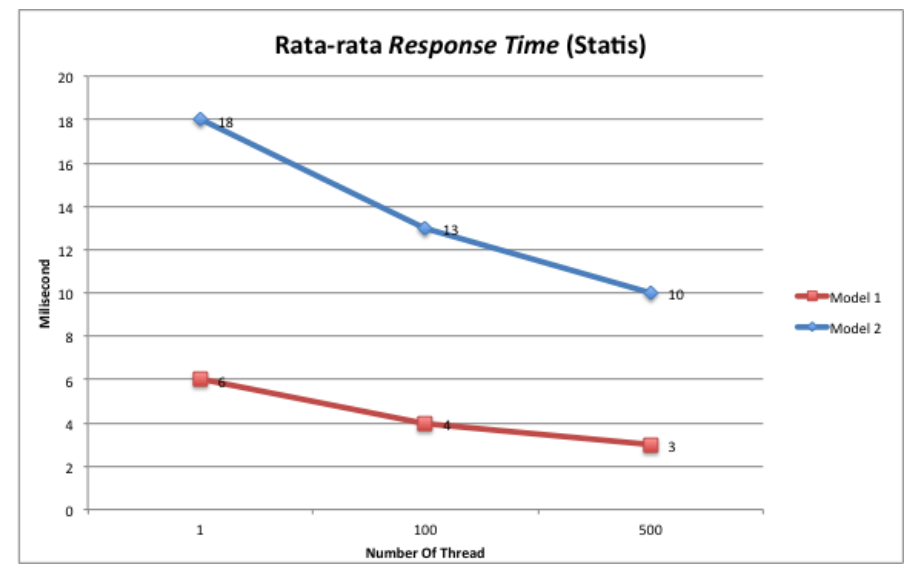

Gambar 7. Grafik waktu rata-rata dari satu kali hasil pengujian pada halaman statis Model 1 dan Model 2

Selain perbedaan alur (flow) sistem pada model 1 dan model 2, arsitektur web yang menggunakan model 2 juga membutuhkan waktu dalam proses load semua library yang ada pada framework JSF baik yang digunakan oleh sistem ataupun tidak digunakan, sehingga untuk memberikan waktu tanggap model 1 lebih cepat dan efisien.

Untuk pengujian halaman dinamis pada kedua sistem, model 1 masih tetap lebih unggul dalam waktu rata-rata merespon permintaan (respon time) dibandingkan pada model 2 dengan parameter yang sama yaitu concurent user (Number of Thread) 1 , 100, 500 user dengan permintaan data (loop count) 1 dan jumlah periode ramp-up masing-masing 10 detik. Pada pengujian ini Concurent user jumlah 1 dan 100 user seluruh permintaan data dapat direspon dan diproses oleh sistem. Sedangkan Concurent user (Number of Thread) 500 pada Model 2 mengalami bottleneck dimana sistem dan layanan server tidak dapat merespon permintaan user, dimana parameter pengujian yang terdiri dari 6.015 data persentasi jumlah permintaan yang gagal 69,60\% dengan waktu tunggu (delay) 1 detik, demikian pada jumlah data 12.027 persentasi jumlah permintaan yang gagal adalah $89,80 \%$ dengan waktu tunggu 0,2 detik. Sebaliknya pada Model 1 dengan concurent user (Number of Thread) 500 
semua permintaan data berhasil ditampilkan pada sisi pengguna (user) dan kegagalan $0 \%$.

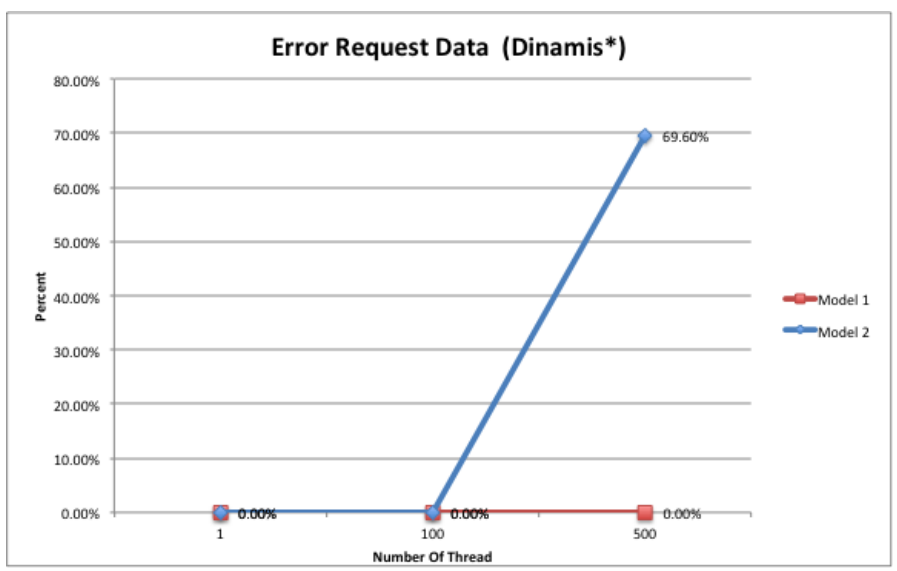

Gambar 8. Grafik persentasi jumlah permintaan yang gagal (kesalahan) dengan jumlah 6.015 data

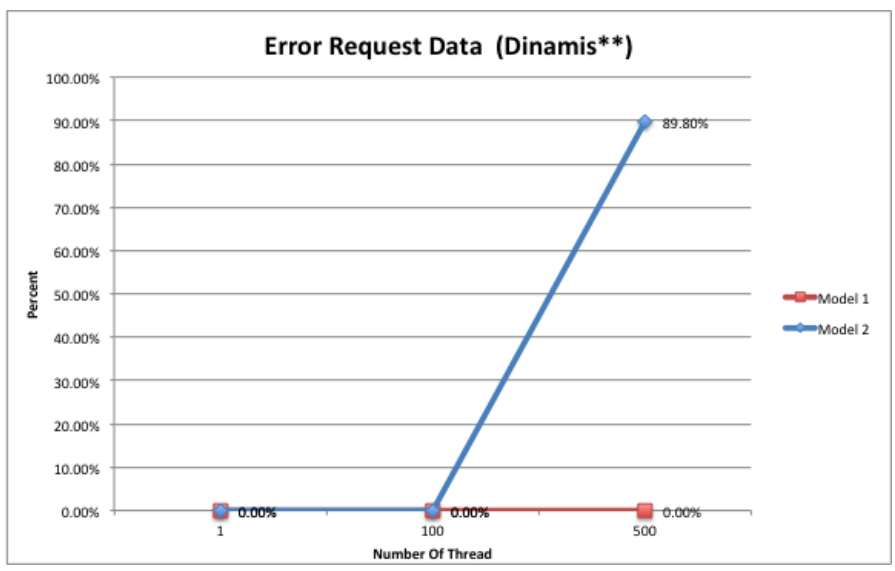

Gambar 9. Grafik persentasi jumlah permintaan yang gagal (kesalahan) dengan jumlah 12.027 data

\section{Penggunaan Resource Memory dan CPU}

Pada hasil pengujian model 1, jumlah thread mempengaruhi penggunaan resource memory dan CPU dimana hasil yang didapatkan dengan jumlah thread yang sama dengan stack size yang sama terjadi peningkatan penggunaan resource memory dan CPU. Hasil pengujian ini dapat dilihat pada Tabel 5.

Tabel 5. Eksperimen Thread berbeda dengan Stack size 1024 KB pada model 1

\begin{tabular}{llrrr}
$\begin{array}{l}\text { Jumlah } \\
\text { Thread }\end{array}$ & $\begin{array}{l}\text { Stack size } \\
\text { (MB) }\end{array}$ & $\begin{array}{l}\text { Resource } \\
\text { CPU }\end{array}$ & $\begin{array}{l}\text { Memory } \\
\text { (MB) }\end{array}$ & Ket. \\
\hline 100 & 1 & 13.30 & 322.95 & Berhasil \\
\hline
\end{tabular}




\begin{tabular}{llrrl}
\hline $\begin{array}{l}\text { Jumlah } \\
\text { Thread }\end{array}$ & $\begin{array}{l}\text { Stack size } \\
\text { (MB) }\end{array}$ & $\begin{array}{l}\text { Resource } \\
\text { CPU }\end{array}$ & $\begin{array}{l}\text { Memory } \\
\text { (MB) }\end{array}$ & Ket. \\
\hline 200 & 1 & 13.98 & 336.55 & Berhasil \\
400 & 1 & 18.39 & 338.31 & Berhasil \\
800 & 1 & 22.87 & 371.16 & Berhasil \\
2000 & 1 & 31.15 & 596.88 & Berhasil \\
5000 & 1 & 0 & 0 & Berhenti \\
\hline
\end{tabular}

Begitu pula pada jumlah thread yang sama dengan stack size yang berbeda terjadi peningkatan penggunaan resource memori dimana semakin tinggi nilai stack size yang diberikan maka penggunaan resource memori juga yang dibutuhkan besar. Akan tetapi stack size yang paling banyak penggunaan resource CPU terjadi pada stack size $1 \mathrm{MB}$ yaitu $13.30 \%$, hal ini terjadi dikarenakan alokasi limit memori yang diberikan sedikit yaitu 1024KB dengan menangani proses thread yang banyak sehingga beban pada CPU akan meningkat seperti terlihat pada Tabel 6.

Tabel 6. Eksperimen Thread 100 dengan stack size berbeda pada Model 1

\begin{tabular}{llrrl}
\hline $\begin{array}{l}\text { Jumlah } \\
\text { Thread }\end{array}$ & $\begin{array}{l}\text { Stack size } \\
\text { (MB) }\end{array}$ & \multicolumn{1}{l}{$\begin{array}{l}\text { Resource } \\
\text { CPU }\end{array}$} & $\begin{array}{l}\text { Memory } \\
\text { (MB) }\end{array}$ & Ket. \\
\hline & 1 & 13.30 & 322.95 & Berhasil \\
& 2 & 11.35 & 945.08 & Berhasil \\
& 4 & 11.11 & 1324.36 & Berhasil \\
100 & 8 & 11.43 & 1206.81 & Berhasil \\
& 16 & 11.21 & 1337.04 & Berhasil \\
& 32 & 11.13 & 1481.71 & Berhasil \\
& 64 & 11.62 & 1620.68 & Berhasil \\
\hline
\end{tabular}

Hal serupa juga berlaku pada pengujian arsitektur model 2, dimana penggunaan resource memory dan CPU meningkat pada jumlah thread dan stack size yang nilainya lebih besar .

\section{SIMPULAN}

Telah dibuktikan bahwa dalam implementasi arsitektur web dengan load dan scalability testing menggunakan Apache Jmeter, waktu rata-rata yang dibutuhkan web Model 1 untuk merespon permintaan user lebih cepat dan efisien dengan jumlah concurent user (number of thread) yang banyak dalam waktu bersamaan dibanding model 2 (MVC) begitu juga pada penggunaan resource memori dan CPU Model 1 lebih unggul. Model 2 memerlukan waktu untuk melakukan load library dan parser kode (source) dalam hal interaksi pola karena pemisahan bagian kode yaitu Model View - Controller, semakin banyak dilakukan pemisahan dan penggunaan library 
pada implementasi model web maka waktu untuk merespon permintaan user mengalami nilai response time yang tinggi dan membutuhkan resource memory dan CPU yang besar. Selain itu, perubahan nilai stack size pada sistem operasi juga mempengaruhi kinerja aplikasi web dimana semakin tinggi nilai stack size maka kebutuhan memori semakin besar pula

\section{REFERENSI}

[1] Gunawan. 2010. Implementasi Model View Controller (MVC) menggunakan Framework JavaServer Faces (JSF) pada Web Perpustakaan UIN Alauddin Makassar. Proceedings: International Conference on Education Technology Strengthening (IC-ETS) 2011. State University of Malang.

[2] Widiyanto, N. 2010. Membangun Aplikasi Java Enterprise dengan Arsitektur Model View Controller (MVC). Yogyakarta: Andi.

[3] Utpatadevi, Sudana, dan Cahyawan. 2012. Implementation of MVC (ModelView-Controller) Architectural to Academic Management Information System with Android Platform Base. International Journal of Computer Applications. Vol. 57(8): 1-6.

[4] Bauer, C., King, G. 2007. Java Persistence with Hibernate. New York: Manning Publications Co. 